\title{
OPORTUNIDADE DE EDUCAÇÃO PARA O PESSOAL NUMEROSO DE ENFERMAGEM: EXAMES SUPLETIVOS
}

\section{FUNDAMENTAÇO์ES}

O Brasil é, em potencial, uma grande nação do mundo. No campo da enfermagem deverá exercer influência mundial notável. Exemplo: em 1961, ao advento da Lei de Diretrizes e Bases, dois pontos foram firmados: o ensino de graduação de enfermagem situou-se plenamente no ensino de 3.0 Grau, universitário; e a formação de técnicos de enfermagem tornou-se norma legal. Hoje, não só os enfermeiros e obstetrizes estão se desenvolvendo, dentro dos recursos do ensino nas universidades, como os técricas de enfermagem estão aumentando de número. $O$ exercício dos técricos de enfermagem plenamente legislado, uma vez que o Conselho Federal de Enfermagem aprovou, em 1975, Resolução, publicada no Diário Oficial da União, que the dá direito à inscrição nos COREN. Não há dúvida de que, tal como o enfermeiro, a obstetriz e os auxiliares de enfermagem, eles exercem atividades de enfermagem. A legislação destes três está clara no texto do Art. $50^{\circ}$ da Lei $n^{\circ}$ 2.604, de 1955. Quanto ao técnico de enfermagem, ele, tal como aqueles três citados, tem também Carteira de Inscrição do COREN. O Conselho Federal de Enfermaßem lhes deu a autorização para exercer atividades de enfermagem.

Baseado em qual lei o COFEN deu o direito ao técnico de enfermagem? Na Lei n. 5.692, de 1971, que rege seu curso.

Em 1972, a Organização Mundial de Saúde estudou a formação de enfermeiros na Europa. Como resultado, as paises desse Continente e mais os da Comunidade Britânica resolveram aprovar a Resolução de formar o enfermeiro em curso universitário (separando o nivel superior do nivel médio). E claro que há muitos anos já havia curso universitário para o enfermeiro, mas havia diferentes modalidades, e direitos decorrentes de sua junção com os técricos.

Como corolário dessa ascensão educacional dos enfermeiros, no mundo, surge, em hierarquia imediatamente a eles ligada, a categoria dos técnicos de enfermagem.

Feitos estes comentários sobre as enfermeiros e obstetrizes e suas oportunidades melhoradas, no Brasil e no mundo, voltemos nossa atenção para os técricos de enfermagem. 
Devem os técnicos resolver como conseguir uma tribuna para exprimirem suas aspirações ccmo grupo dentro da enfermagem. Em 1971, em Manaus, a $A B E n$ dentre as alterações que fez em seu Estatuto, incluniu uma que manda aceitar, como membro da $A B E n$, o técnico de enfermagem que desejar entrar para essa entidade cultural. Seu direito de ser Delegado às Assembléias é certo e já tem sido exercido, como se verificou em 1976, nas reuniōes da Assambléia de Delegados no Hotel Nacional-Rio.

\section{TECNICOS E AUXILIARES DE ENFERMAGEM}

O grupo ocupacional dos técnicos de enfermagem deverá ser, nestes próximos anos, aumentado substanaialmente pela via dos exames supletivos.

$A$ palavra de ordem, nos meios das classes de pessoal de enfermagem ć: aumentar os graduados, isto é, enfermeiros e obstetrizes de 3.० Grau; aumentar os técricos de enfermagem e auxiliares de enfermagem de $2 .^{\circ}$ Grau; e diminuir, como resultado, o número de atendentes nos serviços de saúde.

Todo o atendente que puder, deve estudar e habilitar-se a ser auxiliar, técnico, enfermeiro ou obstetriz. Por que meio o fará? $A$ via supletiva serve para o levar a técnico de enfermagem (Lei n. 5.692, de 1971); brevemente, por Parecer do Conselho Federal de Educação, deverá ser disciplinado o supletivo para Auxiliar de Enfermagem.

$O$ resultado esperado dessas mudanças é a possibilidade de se oferecer serviço de enfermagem digno deste nome. Os que necess:tam de assistência de enfermagem estão aí, a merecer de nós o melhor: queremos dar-lhes o bom tratamento de enfermagem. E de esperar-se que o pessaal formado nos cursos próprios esteja habilitado a trabalhar melhor, com maior segurança para o paciente, do que o pessoal que não teve formação de enfermagem. Devemos todos fazer esforço: divulguemos a oportunidade de habilitação pela via supletiva; e a oportunidade de todo o pessoal de enfermagem ser inscrito (ou provissionado, no caso de ser dessa categoria) no COREN.

\section{HAYDEE GUANAIS DOURADO}

